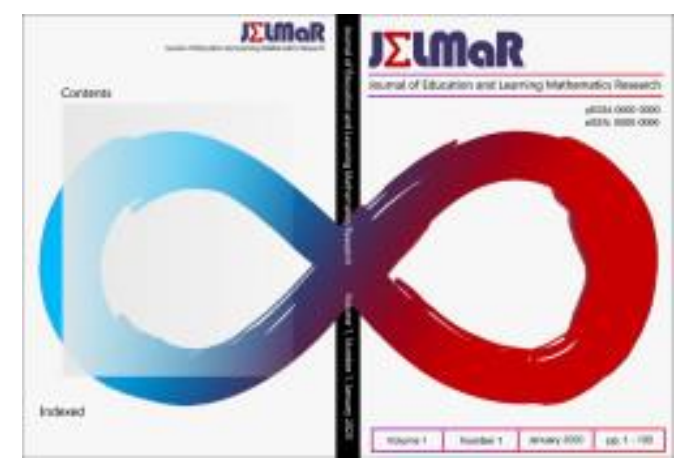

Journal of Education and Learning Mathematics Research (JELMaR)

Online ISSN $\quad:$ 2715-9787

Print ISSN : :2715-8535

Journal Homepage : http://jelmar.wisnuwardhana.ac.id/index.php/jelmar/index

\title{
Cognitive Level Analysis of Problems in Mathematics Textbook Class XII Revision 2018 Materials of Congress and Construction Based on the Revised Bloom Taxonomy
}

\section{Dira Oktia Mita*, Ringki Agustinsa \& Edi Susanto}

To cite this article: Mita, D., Agustinsa, R., \& Susanto, E. (2021). Cognitive Level Analysis of Problems in Mathematics Textbook Class XII Revision 2018 Materials of Congress and Construction Based on the Revised Bloom Taxonomy. Journal of Education and Learning Mathematics Research (JELMaR), 2(2), 14-25. https://doi.org/10.37303/jelmar.v2i2.56

To link this article : https:// doi.org/10.37303/jelmar.v2i2.56

\section{Publisher}

Department of Mathematics Education,

Faculty of Teacher Training and Education,

Universitas Wisnuwardhana Malang 


\title{
Cognitive Level Analysis of Problems in Mathematics Textbook Class XII Revision 2018 Materials of Congress and Construction Based on The Revised Bloom Taxonomy
}

\author{
Dira Oktia Mita ${ }^{1 *}$, Ringki Agustinsa ${ }^{2}$, Edi Susanto ${ }^{3}$ \\ JPMIPA FKIP Mathematics Education Study Program, Bengkulu University \\ e-mail: diraokti@@gmail.com
}

\begin{abstract}
This study aims to describe the distribution of cognitive levels of questions in the 2018 Revised Class XII Mathematics Textbook for Congruence and Similarity Based on Bloom's Taxonomy. Bloom's Taxonomy used is a revised Bloom's Taxonomy with cognitive process dimensions consisting of: remembering(C1), understanding(C2), applying(C3), analyzing $(C 4)$, evaluating(C5), and creating(C6). This type of research was descriptive research with a qualitative approach. Sources of data in this study were questions about the material congruence, similarity and competency test questions contained in the mathematics textbooks of class XII students. The research was carried out with the method of collecting documentation data and using research instruments in the form of analysis sheets and analysis conformity sheets. The results showed that the distribution of the cognitive level of questions on the congruence and similarity material contained the cognitive level of understanding(C2) as much as $18.2 \%$, applying(C3) as much as $50 \%$ and analyzing(C4) as much as $31.8 \%$, with the dominant cognitive level being cognitive level of applying(C3) and does not include cognitive levels of remembering(C1), evaluating(C2) and creating(C6). So it was found that the distribution of the cognitive level of the questions on the material of congruence and similarity topic did not vary or was not proportional.
\end{abstract}

Keywords: Mathematics Textbook, Congruence, Similarity, Question, Revised Bloom's Taxonomy, Cognitive Level.

\section{INTRODUCTION}

Mathematics has a very important role in everyday life. Almost all sciences require mathematics as a tool, especially the exact sciences. Understanding the material provided so that different learning outcomes are obtained for each individual. The learning outcomes obtained by students depend on the delivery of educators in the learning process. To determine the ability of students and the quality of educators in the learning process, one way that can be done is through evaluation (Ratnawulan and Rusdiana, 2014).

Evaluation can be done to measure the cognitive learning outcomes of students regarding the mastery of teaching materials in accordance with the educational objectives and lessons that have been obtained (Wijaya, Eresti, Despa \& Walid, 2019:58). Evaluation aims to see learning achievement and make improvements that are lacking. In fact, many teachers' actions are not appropriate due to inappropriate evaluation tools. Therefore, it is important to conduct an analysis of these problems, one of which is by analyzing teaching materials. 
Teaching materials are a set of scientific knowledge that is described from the curriculum to be conveyed or discussed in the teaching and learning process in order to arrive at the goals that have been set (Sudjana, 2011:22). So, teaching materials are one of the most important learning tools in the learning process to achieve the goals of the learning process. One example of teaching materials that are commonly used are textbooks.

The 2018 revised Grade XII Mathematics textbook is one of the teaching materials published by the Ministry of Education and Culture of the Republic of Indonesia. This book is often used in schools, one of which is SMA Negeri 2 Bengkulu Utara. This book was written using the 2013 Curriculum where this curriculum has several objectives, namely: (1) improving intellectual abilities, especially high-level students' abilities, (2) forming students' abilities in solving problems systematically, (3) obtaining high learning outcomes, (4) train students in communicating ideas, especially in writing scientific papers and (5) develop students' character.

The 2018 revised class XII mathematics textbook contains 4 chapters, one of which is congruence and similarity material. In studying congruence and congruence material, most of the questions are presented in the form of images so that it requires a process of changing what is known from images into written language and vice versa from written language is converted into image form and does not rule out the possibility of a relationship between the concepts of congruence and similarity with other math concepts (Kusumawati, 2014:115). This material is also very useful in everyday life, one of which is being able to know the height of a building without having to measure it directly. In this material presented questions in the form of problems, practice questions and competency test questions where each question has a different cognitive level. The cognitive level of the questions needs to be known to make it easier for educators to provide the right questions for their students and for students as well to make it easier to understand the material given (Susanti, Trapsilasiwi \& Kurniati, 2015:2). The cognitive level of the questions in the book is not yet known, so an analysis is needed. To find out the cognitive level of the question, a theory that discusses the cognitive level is needed. One theory that discusses the cognitive level is Bloom's Taxonomy theory.

Bloom's taxonomy is a hierarchical (tiered) structure that identifies thinking skills from low to high levels. Bloom's Taxonomy was first coined by an educational psychologist from the United States named Benjamin S. Bloom in 1950. Then, along with the development of educational theory, Krathwohl and psychologists of the flow of cognitivism improved Bloom's Taxonomy to suit the times. The results of these improvements were published in 2001 under the name Revised Bloom's Taxonomy. Revised Bloom's Taxonomy has two dimensions, namely the dimensions of cognitive processes and knowledge. The cognitive process dimension contains six categories, namely: remembering, understanding, applying, evaluating, and creating (Anderson and Krathwohl, 2010:6).

Several researchers have conducted research using Revised Bloom's Taxonomy theory, one of which was carried out by Susanti, Trapsilasiwi, and Kurniati regarding the analysis of the cognitive level of competency testing in the Mathematics Electronic School Book (BSE) of SMP/MTs grade VII curriculum 2013 based on Bloom's Taxonomy, the results of research conducted it was found that the BSE Mathematics competency test questions in semester 1 included 9 variations of questions from 24 variations of questions according to the cognitive level of the Revised Bloom's Taxonomy. Of the 166 questions, there is a $6.6 \%$ C2-factual level; $17 \%$ C2-conceptual level; 22\% C2-procedural level; 3\% C3factual rate; 6.6\% C3-conceptual level; 28\% C3-procedural level; 1.8\% C4-conceptual level; 14\% C4-procedural level; 0.6\% C6-conceptual level; and 0\% other level questions (Susanti, Trapsilasiwi \& Kurniati, 2015:1). The uneven proportion of questions shows the weakness 
of the mathematics textbooks used. Therefore, there is a need for a special study, especially regarding the cognitive level of the questions used in mathematics textbooks as an evaluation so that the quality of the questions made is better.

Based on the description of the background above, an analysis will be carried out regarding "Analysis of the cognitive level of questions in the class XII mathematics textbook revision 2018 material congruence and similarity based on the revised Bloom's taxonomy".

\section{METHOD}

This type of research is descriptive research with a qualitative approach. Descriptive research is research conducted to determine the value of independent variables, either one or more (independent) variables without making comparisons or connecting with other variables (Darna and Herlina, 2018:289). This research was conducted to determine the value of each variable, either one or more variables. The research that will be carried out is to analyze the cognitive level of the questions in the 2018 revision of class XII mathematics textbooks on congruence and similarity based on Bloom's Taxonomy and make the percentage of the cognitive level of the questions. This study uses a mathematics textbook, namely the 2013 revised 2013 edition of the Mathematics textbook for SMA/MA/SMK/MAK class XII which was compiled by Abdur Rahman As'ari, et al. Publisher Center for Curriculum and Books, Balitbang Kemendikbud. The research data sources used were questions in the 2018 revised class XII mathematics book, congruence and similarity material. The instrument used in this study was a cognitive level analysis sheet.

Table 1. Cognitive Level Indicators Revised Bloom's Taxonomy

\begin{tabular}{|c|c|c|c|}
\hline No & $\begin{array}{c}\text { Cognitive } \\
\text { Level }\end{array}$ & Category & Indicator \\
\hline \multirow[t]{2}{*}{1} & $\begin{array}{l}\text { Remembering } \\
\text { (C1) }\end{array}$ & Recognize & $\begin{array}{l}\text { 1. Given the kinds of flat shapes and their nature } \\
\text { 2. Remember the sine and cosine rules and adapt to the } \\
\text { concept of congruence } \\
\text { 3. Remembering the sine and cosine rules and adapting } \\
\text { to the concept of congruence } \\
\text { 4. Given the formula for rotation of a triangle with } \\
\text { center } \mathrm{O}(0,0) \text { counterclockwise } \\
\text { 5. Given the triangular dilatation formula with a scale } \\
\text { factor }\end{array}$ \\
\hline & & Recalling & $\begin{array}{l}\text { 1. Rewrite the conditions for congruent triangles, that } \\
\text { is, two triangles are said to be congruent if the } \\
\text { corresponding sides and angles are congruent. } \\
\text { 2. Rewrite the conditions for congruent triangles, that } \\
\text { is, two triangles are said to be congruent if the ratios } \\
\text { of the corresponding sides and angles are equal. }\end{array}$ \\
\hline 2 & $\begin{array}{l}\text { Understanding } \\
\text { (C2) }\end{array}$ & Interpret & $\begin{array}{l}\text { 1. Changing congruent terms into symbols or symbols } \\
\text { 2. Changing similar terms into symbols or symbols } \\
\text { 3. Make an example of a shadow in a triangle } \\
\text { 4. Inserting a rotational shadow value into the image } \\
\text { 5. Entering the dilated shadow value into the image } \\
\text { 6. Creating a triangular shadow image from the } \\
\text { rotation } \\
\text { 7. Creating a triangular shadow image from the results }\end{array}$ \\
\hline
\end{tabular}




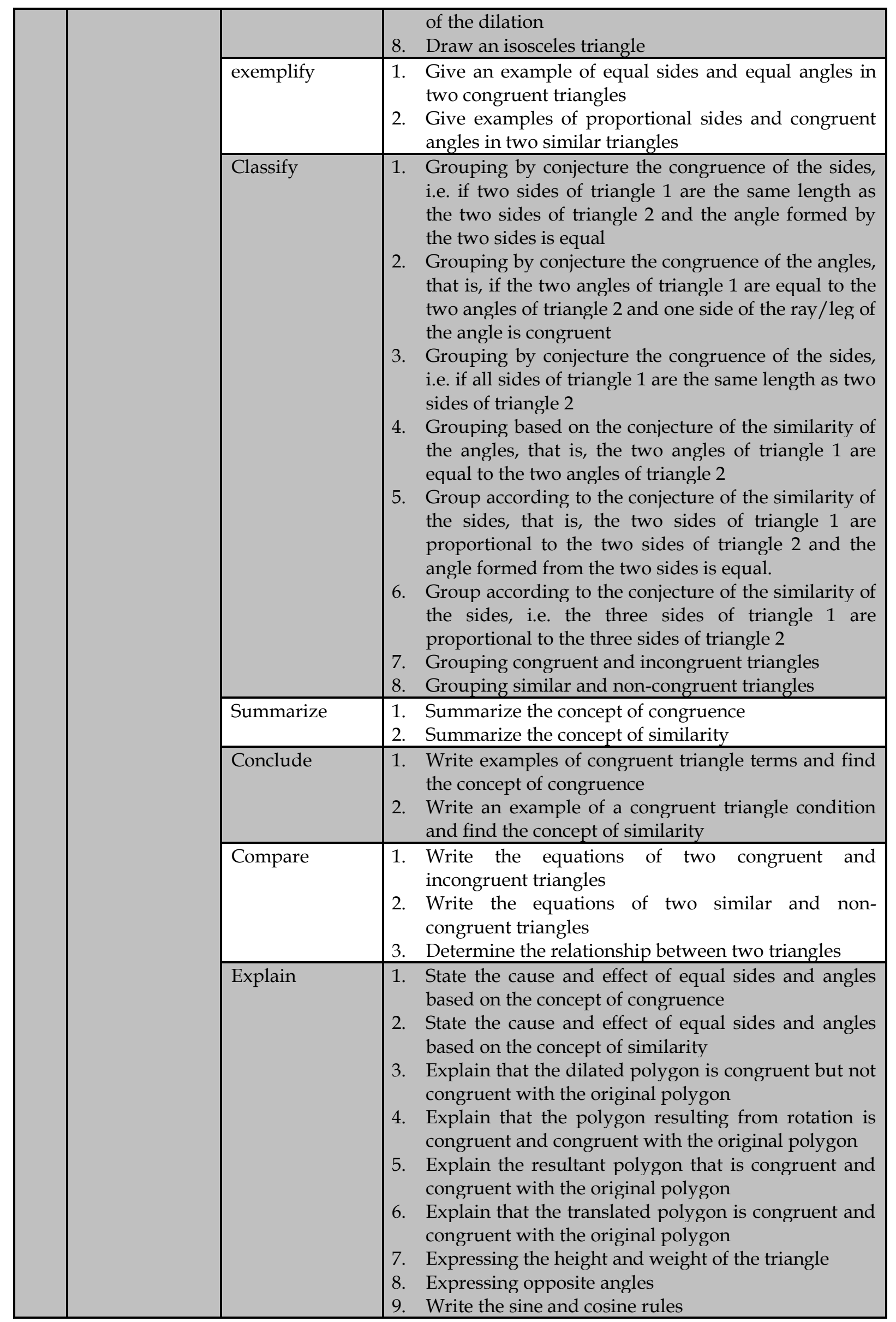




\begin{tabular}{|c|c|c|c|}
\hline & & & $\begin{array}{l}\text { 10. Explain the concept of the ratio of the perimeter and } \\
\text { area of congruent polygons } \\
\text { 11. Explain the concept of the ratio of the perimeter and } \\
\text { area of a polygonal polygon }\end{array}$ \\
\hline \multirow[t]{2}{*}{3} & \multirow[t]{2}{*}{ Apply (C3) } & Execute & $\begin{array}{l}\text { 1. Doing congruence problems with the rules of sines, } \\
\text { cosines and geometric transformations } \\
\text { 2. Solve equations problems using the sine, cosine rules } \\
\text { and geometric transformations } \\
\text { 3. Finding the unknown side lengths in congruent } \\
\text { triangles } \\
\text { 4. Find the length of the unknown side of a similar } \\
\text { triangle using side ratio } \\
\text { 5. Find the lengths of the sides and the measure of the } \\
\text { angles in congruent triangles using the sine and } \\
\text { cosine rules } \\
\text { 6. Find the lengths of the sides and the measure of the } \\
\text { angles in a similar triangle using the sine and cosine } \\
\text { rules } \\
\text { 7. Using the concepts of congruence } \\
\text { 8. Using the concepts of similarity } \\
\text { 9. Calculating the results of the dilatation of polygons } \\
\text { 10. Calculating the result of the translation of polygons } \\
\text { 11. Calculating the result of rotation of polygons } \\
\text { 12. Calculate the result of rotation of a triangle with } \\
\text { center } O(0,0) \text { counterclockwise } \\
\text { 13. Calculating the result of triangular dilatation } \\
\text { 14. Finding the unknown point value in Cartesian } \\
\text { coordinates }\end{array}$ \\
\hline & & Implement & $\begin{array}{l}\text { 1. Finding the ratio of the perimeters of congruent } \\
\text { triangles } \\
\text { 2. Find the ratio of the perimeters of similar triangles } \\
\text { 3. Finding the ratio of the areas of congruent triangles } \\
\text { 4. Find the ratio of the areas of similar triangles }\end{array}$ \\
\hline \multirow[t]{3}{*}{4} & \multirow[t]{3}{*}{ Analyze (C4) } & Differentiate & $\begin{array}{l}\text { 1. Distinguish between relevant or important and } \\
\text { unimportant parts in congruence } \\
\text { 2. Distinguish between relevant or important and } \\
\text { unimportant parts of congruence }\end{array}$ \\
\hline & & Organize & $\begin{array}{l}\text { 1. Proving the congruence of two triangles } \\
\text { 2. Proving the similarity of two triangles } \\
\text { 3. Proving the congruence of triangles using a flowchart } \\
\text { in deductive proof } \\
\text { 4. Proving the similarity of triangles using flowcharts in } \\
\text { deductive proofs } \\
\text { 5. Group congruent triangles using the sine and cosine } \\
\text { rules } \\
\text { 6. Group similar triangles using the sine and cosine } \\
\text { rules } \\
\text { 7. Proving the congruence of two rotational shapes } \\
\text { 8. Proving the congruence of two flat shapes resulting } \\
\text { from reflection } \\
\text { 9. Proving the congruence of two translated flat figures } \\
\text { 10. Proving the congruence of two dilated figures } \\
\text { 11. Find the area of the shaded flat shape }\end{array}$ \\
\hline & & Attribute & $\begin{array}{l}\text { 1. Determine the point of view of written or spoken } \\
\text { material }\end{array}$ \\
\hline
\end{tabular}




\begin{tabular}{|c|c|c|c|}
\hline & & & $\begin{array}{l}\text { 2. Gives the result of two congruent triangles } \\
\text { 3. Provide another alternative that can be used in the } \\
\text { concept of congruent triangles } \\
\text { 4. Provide another alternative that can be used in the } \\
\text { concept of similarity triangle }\end{array}$ \\
\hline \multirow[t]{2}{*}{5} & \multirow[t]{2}{*}{ Evaluate (C5) } & Check & $\begin{array}{l}\text { 1. Testing the suitability of the conclusions of the } \\
\text { triangle is said to be congruent with the concept of } \\
\text { congruence } \\
\text { 2. Testing the suitability of the conclusions of the } \\
\text { triangle is said to be congruent with the concept of } \\
\text { congruence }\end{array}$ \\
\hline & & Criticize & $\begin{array}{l}\text { Assessing a product or process based on the stated } \\
\text { criteria }\end{array}$ \\
\hline \multirow[t]{3}{*}{6} & \multirow[t]{3}{*}{ Create (C6) } & Formulate & Provide a solution to a problem \\
\hline & & Plan & Creating problem solving methods \\
\hline & & Produce & $\begin{array}{l}\text { Creating a new product that fits the given } \\
\text { product/image }\end{array}$ \\
\hline
\end{tabular}

The steps of data analysis carried out are as follows:

1. Analyze questions based on cognitive level Revised Bloom's Taxonomy

2. Calculate the percentage of cognitive level based on the revised Bloom's Taxonomy using the following formula:

$$
P_{i}=\frac{N_{i}}{N} \times 100 \%
$$

( Lestari and Yudhanegara, 2018:200)

Information :

$P_{i}=$ the percentage of the number of questions categorized at the $\mathrm{i}$-th cognitive level, starting from C1, C2, C3, C4, C5 and C6

$N_{i}=$ number of questions categorized as $\mathrm{C} 1, \mathrm{C} 2, \mathrm{C} 3, \mathrm{C} 4, \mathrm{C} 5$ and $\mathrm{C} 6$

$N=$ number of questions

3. The results of the analysis of the cognitive level of questions based on the assessment of researchers and colleagues based on the revised Bloom's Taxonomy can use the stratified Spearman correlation test (the rank correlation test). Calculation of the correlation coefficient can use Microsoft excel or use the Spearman rank correlation formula, namely:

$$
\rho=1-\frac{6 \sum D_{i}^{2}}{n\left(n^{2}-1\right)}
$$

(Lestari and Yudhanegara, 2018:200)

Information :

$\rho=$ Spearman Rank correlation coefficient 
$\mathrm{Di}=$ difference between the two rankings of each observer

$\sum D_{i}^{2}=$ total square of the difference between the two rankings of each observation

$n=$ amount

Table 2. Interval of Correlation Coefficient Value and Relationship Strength

\begin{tabular}{lll}
\hline No & \multicolumn{1}{c}{$\begin{array}{c}\text { Correlation Coefficient } \\
\text { Interval }\end{array}$} & \multicolumn{1}{c}{ Relationship Strength } \\
\hline $\mathbf{1}$ & $\rho=0.00 \quad$ & There is not any \\
$\mathbf{2}$ & $0.00<\rho \leq 0.20$ & Very low \\
$\mathbf{3}$ & $0.20<\rho \leq 0.40$ & Low \\
$\mathbf{4}$ & $0.40<\rho \leq 0.70$ & Enough \\
$\mathbf{5}$ & $0.70<\rho \leq 0.90$ & Tall \\
$\mathbf{6}$ & $0.90<\rho<1.00$ & Very high \\
$\mathbf{7}$ & $\rho=1,00$ & Perfect \\
\hline & & \multicolumn{1}{c}{ (Misbahuddin and Hasan, 2014:48) }
\end{tabular}

\section{RESULTS AND DISCUSSION}

Questions in congruence and congruence material in mathematics textbooks for class XII curriculum 2013 revised edition 2018 SMA/MA/SMK/MAK class XII include congruence questions, congruence questions and competency test questions consisting of 32 questions. The congruence question consists of 12 questions, the congruence question consists of 10 questions and the competency test question consists of 10 questions. The following is a recapitulation of the results of the analysis of the material congruence and similarity:

Table 3. Recapitulation of the Cognitive Level Distribution of Questions

\begin{tabular}{lccccc}
\hline Cognitive Level & $\begin{array}{c}\text { Material } \\
\text { congruence }\end{array}$ & $\begin{array}{c}\text { Similarity } \\
\text { material }\end{array}$ & $\begin{array}{c}\text { Competency } \\
\text { test questions }\end{array}$ & $\begin{array}{c}\text { Number of } \\
\text { questions }\end{array}$ & Percentage \\
\hline $\begin{array}{l}\text { Remember } \\
\text { (C1) }\end{array}$ & - & - & - & 0 & $0 \%$ \\
$\begin{array}{l}\text { Understand } \\
\text { (C2) }\end{array}$ & $18.2 \%$ & - & - & 8 & $18.2 \%$ \\
$\begin{array}{l}\text { Apply } \\
\text { (C3) }\end{array}$ & $13.6 \%$ & $25 \%$ & $11.4 \%$ & 22 & $50 \%$ \\
$\begin{array}{l}\text { Analyze } \\
\text { (C4) }\end{array}$ & $15.90 \%$ & $4.54 \%$ & $11.36 \%$ & 14 & $31.8 \%$ \\
$\begin{array}{l}\text { Evaluate } \\
\text { (C5) }\end{array}$ & - & - & - & 0 & $0 \%$ \\
$\begin{array}{l}\text { Create } \\
\text { (C6) }\end{array}$ & - & - & - & 0 & $0 \%$ \\
Amount & $\mathbf{4 7 . 7 \%}$ & $\mathbf{2 9 . 5 4 \%}$ & $\mathbf{2 2 . 7 6 \%}$ & $\mathbf{4 4}$ & $\mathbf{1 0 0 \%}$ \\
\hline
\end{tabular}

From table 3 above, it can be concluded that the questions in the 2018 revised class XII mathematics textbook in congruence and similarity material contain the cognitive level of understanding (C2), applying (C3) and analyzing (C4) with the dominant 
cognitive level being the cognitive level of applying (C3) with the amount of $50 \%$. The questions with cognitive level $\mathrm{C} 2$ can be seen in Figure 1 below in the example question number 5:

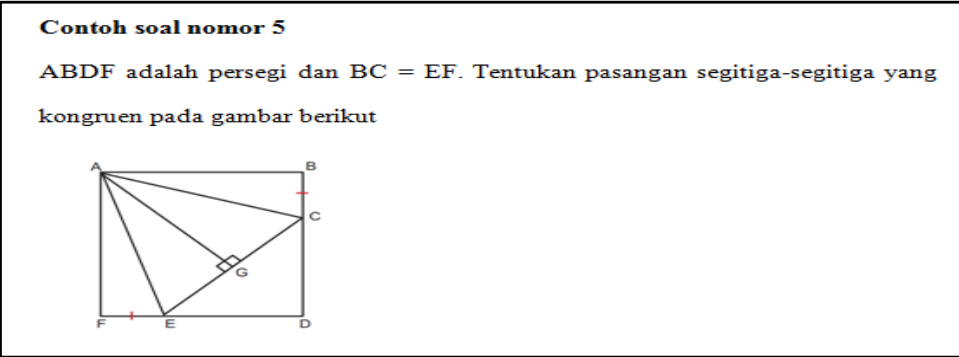

Figure 1. C2 category questions about congruence material

The results of the analysis of figure 1: Students must know and rewrite the terms of a congruent triangle, namely Two triangles are said to be congruent if the corresponding sides and angles are equal (C1). To determine a pair of congruent triangles, students can look at the picture and pair congruent triangles such as triangle $A B C$ and triangle AFE then write down examples of the corresponding sides to meet the requirements of congruent triangles and find the concept of congruence (C2), it is found that and . So the question belongs to the C2 cognitive level (understanding) the category concludes with the indicator writing down examples of congruent triangle conditions and relating to the concept of congruence. $\triangle A B C \cong \triangle A F E \triangle A G C \cong \triangle A G E$

Questions with a cognitive level of C3 obtained as many as 22 questions with a percentage of $50 \%$. One example of a question with a cognitive level of C3 can be seen in Figure 2 in problem 4.2.2:

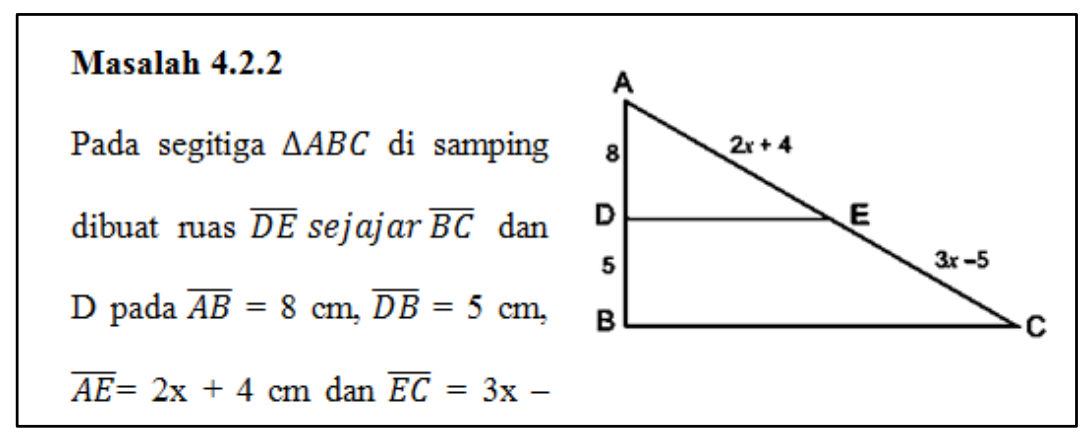

Figure 2. C3 category questions about similarity material

The results of the analysis of Figure 2: To find the length of BC with the concept of congruence of 2 triangles, first, students must recall the conditions for similar triangles, namely that two triangles are said to be congruent if the ratio of the sides and the corresponding angles is equal (C1), if the triangle is congruent then students can give examples of comparable sides and equal angles in two similar triangles (C2) as from the comparison of these sides the value of $x$ is, then to find the length of the unknown side of the triangle which is congruent using the side ratio (C3), namely the length of $\mathrm{BC}$ can use the Pythagorean theorem, then we get $\mathrm{BC}=$. So the question belongs to the $\mathrm{C} 3$ cognitive 
level (applying) the executing category with the indicator looking for an unknown side length in a similar triangle using side comparisons. $\frac{A D}{A B}=\frac{A E}{A C} \frac{30}{7} \frac{78}{7} \sqrt{2}$

As for the C4 cognitive level, there are 14 questions with a percentage of $31.8 \%$ and examples of the questions can be seen in Figure 3 below on the competency test question number 1:

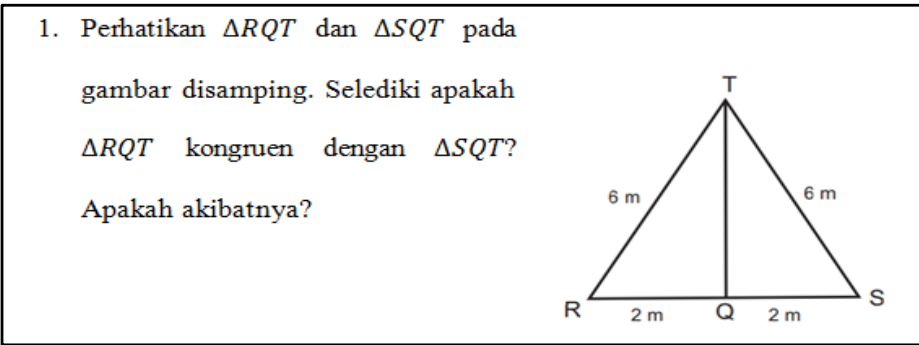

Figure 3. Questions for category C4 competency test questions

Results of image analysis 3: First of all, students rewrite the terms of congruent triangles, namely writing equal sides and angles of 2 congruent triangles (C1), then giving examples of equal sides and angles -Equal angles in two congruent triangles such as RT = $\mathrm{ST}, \mathrm{RQ}=\mathrm{SQ}$ and $\mathrm{TQ}=\mathrm{TQ}(\mathrm{C} 2)$ then by using the congruence concepts (C3) it is found that, then students can give the result of two triangles that congruent (C4) that is large $\triangle R Q T \cong S Q T \angle \mathrm{R}=\angle \mathrm{S}$ and $\angle \mathrm{RTQ}=\angle \mathrm{STQ}$ and $\angle \mathrm{TQR}=\angle \mathrm{TQS}$. So the question belongs to the $\mathrm{C} 4$ cognitive level (analyzes) the attributing category with indicators giving the result of two congruent triangles.

The results of the analysis of the cognitive level that have been carried out by colleagues using the revised Bloom's Taxonomy obtained 41 questions that have similarities with the researcher and 3 different questions with the researcher. The following table describes the differences in the results of the analysis between researchers and colleagues:

Table 4. Recapitulation of Differences in Cognitive Level Analysis of Questions by Researchers and Colleagues Based on Revised Bloom's Taxonomy

\begin{tabular}{ccccc}
\hline \multirow{2}{*}{ About } & \multicolumn{2}{c}{ Cognitive Level } & \multicolumn{2}{c}{$\begin{array}{c}\text { Cognitive Level Appropriateness } \\
\text { Question }\end{array}$} \\
\cline { 2 - 5 } Competency & Test Questions & Peers & YES & NO \\
$\mathbf{1}$ & C4 & C2 & & $\sqrt{ }$ \\
$\mathbf{2}$ & C4 & C2 & & $\sqrt{ }$ \\
$\mathbf{8}$ & C4 & C3 & & $\sqrt{ }$ \\
\hline
\end{tabular}

After that, the results of the cognitive level analysis of the questions carried out by the researcher and his colleagues were seen for the correlation using the Spearman rank test calculation using Microsoft Excel which the results of the correlation analysis of the cognitive level of congruence and similarity material between researchers and colleagues is 0.83 which means that there is a strong relationship between the results of the analysis of researchers and colleagues. 


\section{DISCUSSION}

Based on the results of the analysis carried out, for the questions on the material of congruence and similarity in the 2013 revised edition of the 2018 revised edition of the mathematics textbook for SMA/MA/SMK/MAK class XII compiled by Abdur Rahman As'ari, et al, 2018, the questions in this book has various types of questions with the distribution of cognitive levels found in the cognitive level of understanding (C2), applying (C3), and analyzing (C4). And there were no questions that were included in the cognitive level of remembering (C1), evaluating (C5), and creating (C6).

The distribution of the cognitive level that dominates the congruence and similarity material is a question that is included in the cognitive level of applying (C3). Questions that are classified as understanding (C2) are questions that direct students to draw and explain. Questions that are classified as applying (C3) are questions that direct students to calculate by applying a procedure and using formulas related to congruence and similarity. Then, for the cognitive level analysis question (C4), it is a question that directs students to prove the congruence and congruence of flat figures. It was found that half of the total congruence and similarity questions were in the cognitive application level (C3).

Furthermore, for questions with cognitive levels of remembering (C1), evaluating (C5), and creating (C6) there is no this because for cognitive levels of remembering (C1) it usually leads to recalling a congruence concept such as the sine and cosine formulas. Then for the cognitive level of evaluating (C5) is the cognitive level which usually directs to reexamine and assess something related to the material, Then for the cognitive level of creating (C6) is the cognitive level which usually directs to create a new formula or method that can be used to solve the problem of congruence and similarity. While the congruence and congruence material usually directs students to explain congruence and congruence and use a procedure according to the indicators belonging to the material. So, questions with cognitive levels of remembering (C1), evaluating (C5), and creating (C6) are quite difficult to make and apply to congruence materials. Furthermore, based on the theory, a good cognitive level distribution is as follows: remembering (C1) as much as $5 \%$, understanding (C2) as much as $10 \%$, applying (C3) as much as $45 \%$, analyzing (C4) $25 \%$, evaluating (C5) as much as $10 \%$, and create (C6) as much as $5 \%$ and create (C6) is quite difficult to make and apply to congruent materials. Furthermore, based on the theory, a good cognitive level distribution is as follows: remembering (C1) as much as $5 \%$, understanding (C2) as much as $10 \%$, applying (C3) as much as $45 \%$, analyzing (C4) $25 \%$, evaluating (C5) as much as $10 \%$, and create (C6) as much as $5 \%$ and create (C6) is quite difficult to make and apply to congruent materials. Furthermore, based on the theory, a good cognitive level distribution is as follows: remembering (C1) as much as 5\%, understanding (C2) as much as $10 \%$, applying (C3) as much as $45 \%$, analyzing (C4) $25 \%$, evaluating (C5) as much as 10\%, and create (C6) as much as 5\% (Helmawati, 2019:219). In addition, there is also a theory that says that the questions presented must be realistic and strong, and there are questions that require students to think at higher levels such as analyzing, synthesizing, evaluating and creating (Maemunah and Ramlah, 2019). Meanwhile, based on the results of the study, it was found that the proportion of the distribution of the cognitive level of the problem was not the same as the standard proportion and there were even far different percentages.

The proportion of the cognitive level of the questions studied is different from the standard proportion of the cognitive level that should be, this is because the problems contained in this congruence and similarity material are more dominant in directing students to understand and calculate by applying procedures related to the material being studied, resulting in high percentage of applying (C3). but at other cognitive levels, the percentage is smaller and even far from the standard proportion. In addition, the 
questions contained in this problem only contain essay questions. Description questions usually require students to answer in the form of describing, explaining, comparing, give reasons and other similar forms in accordance with the demands of the question by using their own words and language. Based on this, it can be said that the distribution of cognitive levels of questions is not proportional because for the cognitive level of remembering (C1) nothing which means less than 5\%, understanding (C2) more than $12.5 \%$, applying (C3) more than $20 \%$, analyzing (C4) more than $12.5 \%$, evaluating (C5) nothing which means less than $10 \%$, and creating (C6) nothing which means less than $5 \%$.

\section{CONCLUSION}

The questions on the congruence and similarity material contain the cognitive level of understanding (C2) as much as $18.2 \%$, applying (C3) as much as $50 \%$ and analyzing (C4) as much as $31.8 \%$., with the dominant cognitive level being the level of applying cognitive (C3). and does not contain cognitive levels of remembering (C1), evaluating (C5) and creating (C6). So it was found that the distribution of the cognitive level of the questions on the material of congruence and similarity did not vary or was not proportional.

\section{ACKNOWLEDGMENTS}

We would like to thank all those who have contributed to this research, so that the research can be carried out properly.

\section{REFERENCES}

Anderson, LW, \& Krathwohl, DW (2001). Basic Framework for Learning, Teaching, and Assessment Revised Bloom's Education Taxonomy. Translation by Agung Prihantoro. (2010). Yogyakarta: Student Library.

Ariyana, Y., Pudjiastuti, A., Bestari, R., \& Zamroni. (2019). Handbook of Learning Oriented on Higher-Level Thinking Skills.Jakarta

As'ari, A. R., Chandra, T. D., \& Yuwono, I. (2018). Matematika (ke dua).Jakarta: Kementerian Pendidikan dan Kebudayaan.

Darna, N., \& Herlina, E. (2018). Choosing the Right Research Method: For Research in the Field of Management Science. Journal of Management Science, 5(1), 287-292. https://jurnal.unigal.ac.id/index.php/ekonologi/article/view/1359

Helmawati. (2019). HOTS Based Learning and Assessment. Bandung: PT Remaja Rosdakarya

Kusumawati, I. (2014). Identification of the Thinking Process of Middle School Students in Solving Problems Proving Two Congruent Triangles Based on Gender Differences. MATHEdunesa (Scientific Journal of Mathematics Education), 3(3), 114-119. https://jurnalmahasiswa.unesa.ac.id/index.php/mathedunesa/article/view/12774

Lestari, KE, \& Yudhanegara, MR (2018). Mathematics Education Research. Bandung: PT Refika Aditama.

Priatna, N., \& Yuliardi, R. (2019). Mathematics Learning for Elementary School Teachers and Prospective Elementary Teachers. Bandung: PT Remaja Rosdakarya.

Ratnawulan, E., \& Rusdiana, A. (2014). Learning Evaluation. Bandung: Setia Pustaka Bandung 
Sudjana, N. (2011). Assessment of Teaching and Learning Results (6th ed.). Bandung: PT Remaja Rosdakarya.

Susanti, N., Trapsilasiwi, D., \& Kurniati, D. (2015). Analysis of the cognitive level of competency testing on electronic school books (BSE) of mathematics for SMP/MTs grade VII 2013 Curriculum based on Bloom's Taxonomo. Creative-Innovative Mathematics, 1, 65-73. https://doi.org/10.15294/kreano.v6i1.4509 